Santiago Fernandes, antigo pesquisador do Banco do Brasil, iniciou seus estudos de economia em

Nova York, no Institute of American

Banking e na Universidade de Columbia, estagiando no então Chase

Bank e no Federal Reserve Bank, como bolsista da Inter-American

Trade Scholarship. Em 1944,

participou, adido à delegação brasileira, da Conferência de Bretton

Woods que criou o F.M.I. Autor do ensaio Gold - A Barbarous relic e do livro Ouro - A Reliquia bárbara - de

Bretton Woods ao F.M.I. no Rio.

\title{
O Espírito científico de Mauá na trajetória do Banco do Brasil'
}

Sumário - Introduçåo. Causas da curta duração do primeiro banco. O Barbarismo monetário, segundo Mauá. Crítica da teoria clássica da moeda metálica. O Discurso de Mauá na fundação do segundo Banco do Brasil. Crítica de Mauá ao terceiro Banco do Brasil. A Controvérsia entre pluralidade e unidade emissora. Mauá e o Brasil de nossos dias. Conclusão - As Reformas inspiradoras em Mauá.

\section{Reformas inspiradas em nosso maior economista}

"Felizmente para o nascente Império, ao transladar-se temporariamente para o Rio de Janeiro a sede da monarquia portuguesa, em 1808 , havia o príncipe regente criado por decreto régio o primeiro Banco do Brasil... que as idéias desatinadas da época obrigarama liquidar-se" (em 1829).

$$
\text { Visconde de Mauá (1878) }
$$

\section{Introdução}

A trajetória por que passou o Banco do Brasil, na descontinuidade de suas diferentes etapas, está estreitamente relacionada aos erros e à controvérsia, ainda hoje inacabada, em torno da teoria do dinheiro vinculado ao ouro, já que este, de fato, não foi inteiramente desmonetizado. Disso é evidência a paradoxal manutenção de grandes reservas de ouro pelos Bancos Centrais e pelo F.H.I., não obstante a inconversibilidade oficial das moedas nesse metal.
Santiago Fernandes

Dai seu preço absurdamente alto no mercado livre, em decorrência de intensa procura na busca de garantia contra a instabilidade das moedas na atual crise mundial que agrava os desequilibrios de países em desenvolvimento, como o nosso, conduzidos a dividas externas constrangedoras.

Desde que, portanto, se impõe ampla reforma monetária e bancária no campo nacional e internacional - esta encarecida, com veemência, pelo Presidente Figueiredo em seu recente discurso na ONU - parece adequado destacar neste ensaio o pensamento nacional de Mauá sobre a moeda (e o juro) em sua impressionante atualidade. Com isto, acreditamos, talvez seja possível indicar como essa imensa figura de nossa história, que se chamou Irineu Evangelista de Souza (1813-1889), feito Barão e Visconde de Mauá pelos extraordinários serviços prestados ao progresso do Brasil, tem uma dimensão que não foi ainda devidamente mensurada.

O nome de Mauá é, sem dúvida, conhecido e louvado pelos brasileiros la nosso ver nunca no grau em que o merecel como o maior empresário industrial que o Brasil já teve, realizador dos investimentos pioneiros e básicos ligados ao nosso desenvolvimento econômico, já havendo sido cognominado, com justeza, o 'evangelista do progresso nacional'. Também se sabe que prestou serviços ao Brasil no campo da diplomacia, relativamente a problemas com os países do Rio da Prata. Há, todavia, uma faceta de seu gênio que continua desconhecida e rara de encontrar em homens dotados, como ele, de excepcional capacidade de realização prática. Referimo-nos à aptidão para a atividade especulativa, no plano teórico-científico, num campo particu- 
larmente complexo como é o da economia política. Mauá, no entanto, revelou-se capaz disso, saindose com êxito da difícil tarefa, comó já procuramos salientar no capítulo 'A Contribuição científica de Mauá' de nosso livro Ouro - A Relíquia bárbara (1967) e também no artigo Mauá, o economista do Império, para a Revista Brasileira de Economia' labr. jun. 1974). Novos argumentos, apresentados neste ensaio nos levam, todavia, a considerá-lo, hoje, o maior economista surgido no Brasil levando-se em conta sua educação informal e a época de subdesenvolvimento cultural em que viveu.

Com efeito, na investigação em torno do pensamento econômico mais esclarecido em nosso passado, foi grato descobrir que Mauá, visando dotar o Brasil de sistema monetário e bancário que pudesse acelerar o desenvolvimento, bateu-se com as armas superiores da razão científica contra o erro milenar de se confundir o dinheiro com os metais preciosos, erro que foi lamentavelmente consolidado pelos economistas clássicos e por Karl Marx, no séculoXIX².

O estudo da vida e do pensamento de Mauá parece revelar haver ele desenvolvido seu espírito científico na crítica da teorià clássica da moeda metálica e do juro, partindo das observações que fez da experiência monetária e bancária brasileira, relacionada com o primeiro Banco do Brasil. Muito jovem ainda, com 21 anos participou, em 1835, do ato final da liquidação da primeira etapa desse Banco. $\mathrm{O}$ documento que comprova este fato encontra-se publicado em 'O Banco do Brasil' de Victor Viano, mas foi Afonso Arinos de Melo Franco quem chamou atenção para ele, em sua 'História do Banco do Brasil'.

Segundo Mauá, foram "as idéias desatinadas da época" que levaram à extinção do Banco do Brasil, criado por D. João VI. É o que assevera em seu ensaio O Meio circulante do Brasil, de 1878, a nosso ver o mais luminoso trabalho já escrito em nosso país, de crítica à teoria monetária clássica, não só pelo espírito científico que revela, mas pelo que tem de original e precursor de muito do que hoje se admite, e acreditamos, do que se terá que admitir no futuro se tiverem fundamento as reformas delineadas na 'Conclusão' deste ensaio.

\section{Causas da curta duração do primeiro plano}

Os principais historiadores sugerem que, entre as razões que levaram esse Banco a ter duração de 21 anos, de 1808 a 1829, a principal prende-se ao fato histórico que marcou o retorno a Portugal de $\mathrm{D}$. João VI, a 24 de abril de 1821, ou na madrugada de 25 desse mês, segundo outros. Ao se retirarem para
Lisboa, D. João Vle sua corte 'rasparam', por assim dizer, o encaixe de ouro e prata existente no Banco do Brasil, trocando por esses metais que, aliás, já eram ali escassos, as notas de papel-moeda por ele emitidas. Além disso, D. João VI retirou as jóias da coroa, que havia antes depositado no Banco para dar a este maior prestígio e segurança

Diante da concepção da moeda, então vigorante, que supunha necessitarem as emissões de papel-moeda de um lastro de ouro ou prata, é fácil compreender como o fato de ficar o Banco do Brasil sem encaixe metálico contribuiu para desaboná-lo, na opinião de muitos. Embora o alvará que o instituiu por decreto de $\mathrm{D}$. João VI indicasse que ele fora criado com o objetivo de facilitar "os meios e recursos de que as minhas rendas reais e as públicas necessitem para ocorrer às despesas do Estado", o que sugeria o fornecimento de papel-moeda. No entanto, a força do preconceito metálico da moeda fazia com que o Banco não rompesse inteira e abertamente com essa concepção. Dai fazer ele também emissões conversíveis em ouro e prata.

Do descrédito e da difícil situação criada para o Banco, com o comportamento de D. João VI e sua corte, nos oferece eloqüente testemunho a carta dirigida por aquele que viria a ser D. Pedro I a seu pai, em 21 de abril de 1821, na qual sugeria que o Banco, sem ouro e prata, tornara-se 'tísico'. Escrevia D. Pedro I:

"Eu me não vejo envergonhado, depois de me ter sacrificado a ficar no meio de ruínas e em tão desgraçadas como árduas circunstâncias em que ficou a província, que está quase a estourar logo que 0 Banco, o tísico banco, que é o meu termômetro, estiver com o dinheiro exausto (que para isto não faltam nem quatro meses, pelos passos gigantescos com que ele marcha para a cova aberta pelos dilapidadores). Ele de todo já não tem ouro nem prata e só, sim, algum cobre que se tem cunhado depois de fundido. Por conseqüência; como não tem crédito, nem com o que o alcance, os seus bilhetes valem muito pouco, ou quase nada".

Ai está nitidamente patenteado, aos olhos das concepç̃es monetárias do tempo e dos problemas que enfrentava Pedro I, que muito influíra para desacreditar o Banco do Brasil, a circunstância de haverem ficado seus bilhetes sem lastro de ouro e de prata. Segundo os debates da época, efetivamente, o preconceito metálico pesou para a extinção do Banco em 1829 (findo o prazo inicialmente estipulado para a sua existência) sem que os estadistas de então lograssem conseguir sua prorrogação ou sua reorganização. No entanto, Mauá vai nos mostrar o grande serviço prestado ao país, com as emissões de papel-moeda, pelo Banco do Brasil, em período difícil que se seguiu à nossa Independência. 
O Barbarismo monetário segundo Mauá

Recordemos que D. Pedro I, na carta a D. João VI, declarava que, na ausência de ouro e prata, se recorrerá à cunhagem de moedas de cobre. Este fato é o início de um dos mais curiosos e extravagantes fenômenos na história monetária do Brasil, como decorrência do mito da moeda metálica. É que, na ausência de ouro e prata, o Governo resolveu fabricar moedas daquele ordinário metal que passaram a ter preferência sobre as notas emitidas pelo Banco do Brasil. Dessa preferência, verificou o Governo que podia tirar partido, comprando folhas de cobre por preço baixo e cunhando com ele moedas de valor monetário superior ao de seu custo. Isto, porém, fez surgir vasta e ilegal cunhagem de moedas de cobre, praticada nas províncias do Império, contribuindo para a ilegalidade o cobre que vinha, clandestinamente, da Argentina, e dos E.U.A. Esse foi o período da história monetária do Brasil que ficou conhecido pelo nome de 'chen-chen', ou 'chanchan' segundo outros, expressões onomatopaicas relacionadas com o tinir das moedas de cobre.

Mauá, em seu referido ensaio de 1878, fazia a crítica desse período referindo-se à precisão que uma comunidade tem de um meio de troca e à influência do tabu da moeda metálica.

"As necessidades de um meio circulante qualquer - dizia - são tão imperiosas que no Brasil chegamos a imitar as extravagâncias das idéias primitivas a semelhante respeito. Um cobre vil, que não representava metade do valor que seu cunho Ihe imprimia, chegou a ser procurado em várias províncias do Império com 50 a $90 \%$ do prêmio para servir de meio circulante"

Classificava Mauá o período do 'chen-chen' como a "época do barbarismo do sistema monetário do Império". Este - dizia - "felizmente durou pouco, pois até o fim de 1838 se achavam recolhidas, e realizada a troca, não das notas do extinto Banco que as idéias desatinadas da época obrigaram a liquidar-se, porém das cédulas que representavam o cobre de oprobriosa recordação financeira pelo papel-moeda que tinha de servir de motor geral das transações, na importância total de 33.888.122\$000" (mil réis).

Com tais observações, Mauá iria demonstrar que o meio circulante no Brasil teria, necessariamente, que desembocar no papel-moeda, como a melhor forma de dinheiro para o país. Lembrava que logo depois de terem sido encampadas, em 1838, por emissões do Tesouro, as cédulas emitidas para retirar o cobre da circulação, bem como o papelmoeda do extinto Banco do Brasil, já em 1839 - " "as exigências de maior quantidade do instrumento de permutas foram tão clamorosas", que foi novamente decretado um aumento de circulação na importância de 6.075:000\$000. "Boa recordação guardamos" - escrevia Mauá - "das palavras com que foi acolhido esse ato legislativo, pelo acreditado 'Preço Corrente' dessa época, que transmitia ao exterior, mensalmente, as ocorrências financeiras da praça, redigido por Stockmeyer Gracie Hobkierk Co: - "Na Europa mal se poderá compreender que um aumento de notas inconversíveis determinasse um melhoramento sensivel nas condições monetárias deste país."

Comentava então Mauá: - "Obedeciam esses senhores, visivelmente, à opinião que então e sempre condenou o papel-moeda" No entanto acrescentava - "não impediu essa opinião que as urgências da praça se manifestassem e, já em 13 de novembro de 1841 , nova emissão de notas foi autorizada, "sem afetar o valor (cambial) desse papel que continuou a ser exclusivamente regulado pelo valor dos produtos exportáveis, sem nenhuma referência à moeda metálica, cujo valor era completamente dominado por esse papel, não sendo raros os casos em que o câmbio se elevou acima do par!"

Essa experiência monetária do Brasil com o papel-moeda revelava ao espírito indutivo e dedutivo de Mauá, claramente, que o mal não estava propriamente no fato de não terem tais emissões lastro metálico. Isto Ihe vai permitir então fazer notável crítica da teoria da moeda ouro sustentada pela teoria clássica e, como dissemos, por Karl Marx. Em sua análise, Mauá parte do importante papel histórico que exerceu o primeiro Banco do Brasil, com as emissões de papel-moeda no início da nacionalidade, ao mesmo tempo que fazia as mais judiciosas observações a respeito das lacunas da economia política como ciência. Ao salientar que o papel-moeda emitido pelo primeiro Banco teve a maior significação para "atender às exigências peremptórias de uma luta externa em defesa da integridade do território, que a separação da mãe pátria nos entregara como patrimônio nacional", observava ainda Mauá: - "Improvisar recursos para fazer face a tamanhas necessidades nao era fácil tarefa, em uma situação nascente em que o capital ativo era privilégio de pou$\mathrm{cos}$, e nem os elementos que criam a riqueza eram ainda estudados entre nós. Não era isto para estranhar, pois se o estudo da economia política começara já havia algum tempo, em certas nações adiantadas em cultura intelectual, as condições da ciência estavam ainda longe de ser admitidas, e por muitos anos sofreram impugnação. Ainda hoje é matéria duvidosa se todos os princípios apregoados por essa ciência resistem à ação e pressão dos fatos econômicos sempre e em toda parte".

Advertia a seguir Mauá: - "Na verdade, cum- 
pre estar prevenido contra certas idéias apregoadas com dogmática severidade por parte de doutrinários inflexíveis", visto que o "regime aconselhado como salvador de altos interesses para uns daria em resultado ficarem estes seriamente comprometidos em outros, se o bom senso nacional não repelisse o presente de grego, que os chamados mestres da ciência lhe querem impor".

Cremos ser lícito dizer que essas palavras se adequam à irracionalidade do sistema monetário internacional que, desde Bretton Woods até hoje, nos foi imposto pelos dez países mais ricos, sob a liderança dos E.U.A.. Ė o que temos denunciado não só em nosso já mencionado livro como em inúmeros trabalhos pela imprensa e em congressos internacionais ${ }^{3}$. De qualquer forma, se, na época de Mauá, o Brasil caísse no logro de aceitar a ortodoxia da moeda ouro, seria grandemente prejudicado, nas circunstâncias por ele antes referidas. De que maneira, pois, atuou, no início do Império o que Mauá denominou 'bom senso' nacional!?

"Existindo já o Banco do Brasil - dizia Mauá - na época em que necessidades imprevistas e imperiosas, criadas pela luta externa a que nos referimos, exigiam atenção preferente, foi o papel (moeda) desse banco o instrumento que o governo do primeiro reinado encontrou para manobrar, e satisfazer as maiores urgências do Estado, sendo insuficientes o produto dos impostos de que era possível lançar mão, e na ausência de qualquer outro recursosimediato para fazer frente às dificuldades".

Assinala ainda Mauá que a duração da guerra com a Confederação Argentina, "a que o país foi arrastado", determinou a necessidade de copiosas emissões do papel desse banco, "que forçadamente se tornou desde então papel-inconversível", para ressaltar: - "Eis ai a origem de nosso atual meio circulante: único motor das transações monetárias do Brasil há mais de meio século! Como prescindir da origem na apreciação dos grandes fatos econômicose financeiros que a ela se ligam?

\section{Crítica da teoria clássica da moeda metálica}

A seguir, inicia Mauá propriamente sua análise crítica dos postulados da teoria da moeda metálica. Nessa tarefa, serve-se de segura lógica indutiva e dedutiva, sempre amparado na melhor filosofia das ciências empíricas.

Para que o leitor possa ter idéia disso, bastará dar aqui amostra da metodologia de que se utilizou em seu referido OMeio Circulante do Brasil de 1878. A fim de comprovar a falsidade da teoria que susten- tava ser cientificamente indispensável à presença de ouro ou prata no sistema monetário de uma ordem social que baseia sua produção na iniciativa e na propriedade privada, partia Mauá da premissa fundamental, isto é, a conceituação de teoria ou lei científica: - "É com efeito sabido - dizia - que antes que uma teoria consiga firmar-se na base sólida da ciência, tem que pôr à prova as suas conclusões que devem ser invariáveis em todos os paises e em qualquer ocasião; de outro modo perde a teoria aquela base".

Ėoportuno recordar que essa conceituação de teoria científica é negada, para as ciências sociais, pela equívoca doutrina do historicismo germânico que Karl Popper em seu The Poverty of historicism critica adequadamente. É sabido que tambémé negada pela doutrina do chamado materialismo histórico da dialética de Marx e Engels, que tão poderosa influência exerce ainda hoje em tantos espíritos, mesmo não filiados à ortodoxia comunista. Disso é prova a publicação A Dualidade básica da economia brasileira (1957), do defunto ISEB e de autoria de Inácio Rangel, com introdução de Guerreiro Ramos. Ali se pretende que Mauá se enganava naquela conceituação aplicada à economia política.

Ora, ainda que admitida como verdadeira a doutrina do materialismo histórico de Marxe Engels, a conceituação de teoria invocada por Mauá é válida para demonstrar a falsidade de tese da moeda metálica, sustentada por Marx. Pois, o autor de Das Kapital (hoje com todos os seus volumes traduzidos para o português - Ed. Civ. Brasileira) identifica o dinheiro com os metais preciosos em qualquer economia monetária: "Embora ouro e prata não sejam por natureza dinheiro, dinheiro é, por natureza, ouro e prata" - diz Marx. Os leitores poderão verificar essa afirmação, consultando a referida tradução brasileira (I Vol. p. 99), que corresponde ao texto original alemão: "Obgleich Gold und Silber nicht von Natur Gold und Silber ist. Assim, quando Proudhon, contemporâneo de Marx, queria libertar o sistema monetário e bancário do ouro e da prata, propondo sua desmonetização, Marx o criticava dizendo que " $j a-$ mais" (ele grifava esta palavra) o sistema de qualquer economia monetária poderia dispensar os metais preciosos ${ }^{4}$, como insistia no III volume de Das Kapital, em passagem também comentada no capítulo Marx - Defensor do padrão ouro de nosso livro.

Ora, a experiência monetária do Brasil revelava a Mauá, como vimos, que nosso país vivera em condições melhores com papel-moeda, tendo o 'mil-réis' papel, várias vezes, valor superior ao da paridade ouro. Daí, inferir Mauá, corretamente, contra as idéias da moeda metálica: "Não haverá algum grande equívoco no modo de apreciar esta questão, 
da parte daqueles que sustentam idéias que, por mais que se diga não têm base científica, e às quais a prática, ou experiência, dá um desmentido formal?"

Efetivamente, se, como pretendiam os economistas clássicos e Marx, fosse uma lei ou regra científica a exigência da moeda metálica para o funcionamento da chamada economia capitalista, e os dados da experiência no Brasil provavam o contrário, então essa lei ou regra científica (de ambas as escolas) era uma falsa lei, já que uma lei científica não tem exceção: "Nosso país - reiterava Mauá - éo único que dispensou completamente as espécies metálicas da missão principal que o mundo econômico lhe assinalou. Estamos, pois, na exceção. Com ir buscar na regra os meios de melhorar o instrumento de que nos servimos?"

Essas pequenas amostras do raciocínio indutivo e dedutivo de Mauá, são, acreditamos, suficientes para ilustrar a metodologia superior que, surpreendentemente, o norteava, no Brasil de então.

Sua argumentação é sem dúvida adequada para a teoria da moedá em qualquer economia monetária, seja ela de regime socialista de meios de produção, como na União Soviética, China ou Cuba, seja em regime baseado na iniciativa privada, ou semi-socialista, de país democrático ou fascista. Não pode haver uma teoria 'burguesa' da moeda contraposta à teoria 'socialista' já que as funções que o dinheiro deve exercer são exatamente as mesmas. 'Como meio de troca' deve circular sempre, na realização de compras e vendas, e como 'unidade de cálculo' e 'medida' da renda nacional deve ser estável. Nessas duas funções, o dinheiro dispensa os metais preciosos. Não podem, enfim, coexistir dois conceitos de moeda, assim como dois conceitos de metro ou de quilo como unidades de medidas. 0 que pode ser diferente, no tempo e no espaço, é a escolha ou nome das unidades, não o conceito e os princípios científicos que regem as unidades de medida, devendo todas estar submetidas a critérios e condiçס̃es que mantenham estabilidade. No que tange, porém, ao conceito da 'moeda-ouro' como padrão ou medida de valor, valeria dizer que Mauá, partindo da noção científica de 'unidade e padrão' de medida; mostrava o erro de Ricardo e, implicitamente, de Mary ao suporem estes que 'o tempo de trabalho humano' incorporado numa quantidade de ouro servindo de moeda, seria a 'medida do valor'.

Por outro lado, Mauá antecipava a crítica de Keynes aos economistas clássicos cuja teoria levava à convicção de que as crises econômicas não ocorreriam pois a oferta e a procura, para eles, determinariam o equilíbrio econômico natural. Algo que Marx e, antes dele, diga-se, Malthus, Sismondi e Proudhon, denunciaram, corretamente, como falso. Contudo, não pôde Marx perceber, como elimi- nar tais crises, dada sua concepção metálica da moeda e a identificação do regime do laissez-faire com o sistema de produção baseado na iniciativa privada. Outras contribuições de Mauá foram precursoras de teses hoje aceitas, depois da obra de Keynes - distinta do 'keynesianismo vulgar' 5 que levou à atual estagflação nos grandes centros - como a 'possibilidade de cobrir deficits' orçamentários na depressão, com emissões de papel moeda. Estas, todavia, em certos casos - acrescentamos nós - devem ser compensadas por correspondente redução de 'moeda bancária', ou crédito. A soma desses dois tipos de moeda, multiplicada por suas velocidades, constitui, basicamente a demanda global, que deve ser correspondente à produção oferecida no mercado para evitar a inflação.

Não devemos ainda esquecer que Mauá compreendia também que emissões monetárias, mesmo inflacionárias, são irreversíveis ${ }^{6}$. Com isso, ele antecipava, igualmente, a crítica ao grave erro que iria praticar na República, Joaquim Murtinho, no Governo Campos Salles, ao promover o 'resgate' e 'incineração' do papel-moeda, provocando, assim a mais ruinosa depressão econômica por que já passou o pais 7 .

Voltemos, porém, à extinção do primeiro Banco do Brasil, em 1829. Cumpre assinalar que, assim, ficou a capital do Império até 1838, isto é, onze anos, sem qualquer banco privado, e até 1853 sem qualquer banco oficial. Somente no ano de 1838 é que surgiu no Rio de Janeiro o primeiro banco particular, com o nome de Banco Comercial do Rio de Janeiro. Em 1851, porém, Mauá, com 38 anos, compreendeu a necessidade e a oportunidade de outro banco, para aproveitar, como nos relata em sua Exposição aos credores, capitais (poupanças) que se dedicavam ao tráfico de escravos, já extinto. Fundou ele então o segundo banco do Rio de Janeiro, com a denominação de Banco do Brasil, mas sem qualquer vínculo oficial. Pouco depois, em 1853, os dois bancos particulares se fundiram num só, que passou a ser o terceiro Banco do Brasil, ou seja, o segundo com funções oficiais e de banco emissor. Este terceiro Banco do Brasil teve existência até 1900, quando já com o nome de Banco da República do Brasil, foi levado à liquidação no governo de Campos Sales. Isto, pelas mesmas idéias desatinadas que levaram à extinção o primeiro Banco do Brasil, isto é, o dogma da moeda metálica, de que Joaquim Murtinho, então Ministro da Fazenda, era obstinado cultor. Entrando em processo de liquidação o terceiro Banco Oficial (1900), o quarto Banco do Brasil, cuja existência não sofreu interrupção até nossos dias, somente surgiu em 1906, no Governo de Rodrigues Alves.

Focalizemos, entretanto, a seguir, como Mauá nos fornece ainda subsídios para compreen- 
der os erros praticados, até hoje, com relação às taxas de juros, com o atual Banco do Brasil na condição de obsoleta sociedade de economia mista, na qual, sendo o governo majoritário, não tem mais sentido o acionista privado.

\section{O Discurso de Mauá na fundação do segundo Banco do Brasil}

Para melhor comprovar o espírito clarividente de Mauá, e sua cultura impõe-se destacar o pequeno discurso que pronunciou na assembléia de fundação do segundo Banco do Brasil, em 1851, e que nos mostra, já então, preocupado com o desenvolvimento do Brasil pelo aproveitamento do progresso das ciências. Esse documento publicado no Jornal do Comércio, de 2 de março de 1851, tem, a nosso ver, a maior significacão histórica, embora pouco conhecido. Foi Victor Viana, em seu O Banco do Brasil, quem, por assim dizer, salvou esse discurso do esquecimento, transcrevendo-o em seu livro. Aclamado presidente da assembléia de acionistas do novo Banco, Mauá Ihes comunica que o capital no novel instituto fora coberto em poucos dias, o que o levava a enaltecer o 'espírito de associação' comestas palavras:

"Não é sem alguma ufania, senhores, que eu vos comunico este resultado, pois, sendo obtido em três semanas, é na verdade um fato notável que protesta altamente contra a assercão, tantas vezes repetida, que não existe espirito algum de associação entre nós. O que, infelizmente, nos falta, senhores, é a perseverança, a força de vontade tão necessária para alcançar os grandes fins. Quando esta aparece e é convenientemente sustentada, tudo se vence, tudo se consegue.

"O espírito de associação, senhores, é um dos elementos mais fortes da prosperidade de qualquer pais. É, por assim dizer, a alma do progresso. Quando o sábio, em suas meditaçðes, descobre os segredos da natureza, apenas nos mostra o germe; é o espírito de associação quem, desenvolvendo-o, faz crescer a árvore que mais tarde nos brinda com seus frutos sazonados; é o espírito de associação quem faz a grandeza e a prosperidade da Inglaterra, pois, é ele quem fornece os meios de se executarem essas obras gigantescas que, dando um valor a todos os cantos daquela nação, operam essa prodigiosa multiplicação de capitais que ali se observa".

"Éo espírito de associação quem dá aos ingleses os meios de comunicarem os seus pensamentos de um extremo ao outro de sua ilha, com a velocidade do raio, por meio de telégrafos elétricos; descoberta de tão poucos anos e que já dá emprego, só na
Inglaterra, a mais de $70.000 .000 \$ 000$. É o espírito de associação quem faz com que os Estados Unidos, seguindo as pisadas da mãe pátria e emparelhandoa logo, maravilha o mundo com o seu progresso".

"Se, pois, é a essa causa que eu em grande parte atribuo os resultados, por assim dizer fabulosos que se observam em outros países, eu, que ambiciono para o meu país a mesma posição e vantagens, não posso deixar de saudar, com entusiasmo esta reunião que me convence que esse espírito se manifesta também entre nós. Senhores acionistas do novo banco, no meu modo de ver, o estabelecimento de que fazeis parte abre uma picada que, com o andar do tempo, se transformará em larga estrada à prosperidade pública".

Quando meditamos sobre o estado de subdesenvolvimento, em todos os sentidos, especialmente cultural, em que se encontrava, há 131 anos, não só a capital do Império, mas todo o país, podemos melhor apreciar o significado e a grandeza da alocução de Irineu Evangelista de Souza. Em primeiro lugar, não se trata de discurso de rotina, típico da euforia de um banqueiro comum abrindo casa de empréstimos a juro. Mauá fala antes a linguagem do homem público, do estadista. E o que antevia, corretamente, para o banco denominado Banco do Brasil, sem dúvida teria ocorrido, posteriormente, se o banco oficial com esse nome afinasse com uma política visando à estabilidade monetária com juro baixo, sem desemprego.

De qualquer forma, assinalemos que a curta oração de Mauá, cuja forma não podemos deixar de admirar, corresponde a uma época que constitui marco dos mais significativos na história do desenvolvimento econômico do Brasil Império e para o qual Mauá foi, então, a maior força propulsora, pelos investimentos pioneiros que realizou.

Com efeito, se já em 1846 lcom 33 anos apenas) ele desenvolvia a indústria de ferro, com os estaleiros da Ponta da Areia, e em 1848, criava a Companhia de Rebocadores a Vapor. para o Rio Grande do Sul, foi em 1851, no mesmo ano em que fundava o segundo Banco do Brasil, que cuidou de instalar a companhia que inauguraria a luz a gás no Rio, em 1854. Concomitantemente, em 1852, iniciava Mauá os trabalhos para assentar os trilhos da primeira ferrovia no Brasil, com a estrada Rio - Petrópolis, inaugurada também em 1854. Ainda em 1852, obtinha contrato para a realização de um dos seus grandes empreendimentos, que foi o da Companhia de Navegaçãoa Vapor no Amazonas.

Vemos, pois, que a partir de 1846, iniciava Mauá uma série de empreendimentos necessários ao progresso no país e que culminaram naquele que ligou o Brasil à Europa pelo cabo submarino, em 
1874. O que surpreende quando consideramos os meios de comunicação e transporte no Brasil, no meio do século XIX, é verificar que, além de ser homem dotado de assombrosa energia, Mauá tinha uma espécie de dom de ubiqüidade, fundando ao mesmo tempo empresas do Amazonas ao Rio Grande do Sul. Nisso tudo enfrentou ele sempre, como deixa perceber em sua amargurada Exposição aos credores, a mediocridade e a inveja dos pigmeus da época. A propósito, registremos que, ao inaugurar em 1854, a primeira estrada de ferro, na presença do Imperador, dirigia-Ihe estas palavras: "Esta estrada, Senhor, não deve parar e, 'se puder contar com a proteção de V. Majestade', seguramente não parará senão quando tiver assegurada a mais espaçosa das suas estaç̃os na margem esquerda do Rio das VeIhas!"

Parece que Mauá tinha aí premonição de que o Imperador não o ampararia, como de fato não o amparou em 1875, logo depois de haver ligado o Brasil à Europa pelo cabo submarino. Sua interferência poderia ter influído para que o Banco do Brasil (o terceiro) não the negasse o empréstimo de que necessitava, oferecendo Mauá patrimônio imenso como garantia. A recusa do Banco do Brasil levou o vasto império industrial de Mauá à falência. Daí dizer ele que o 17 de maio de 1875 "cravou um punhal fundo no meu coração".

Cremos, por tudo isso, não ser talvez, exagerado dizer que, não fosse a incompreensão de seus contemporâneos e pósteres, o pequeno discurso de Mauá, em 1851, poderia, de certo modo, ser considerado, na história 'econômica' do Brasil, o que foi, para a história 'política' dos E.U.A. a curta oração de Lincoln conhecida como o Gettysburg address (1863). Na verdade, Mauá e Lincoln tiveram muito de fortuna comum, quer na formação auto didática, quer no destino de serem mortos pelas forças retrogadas. Lincoln fisicamente e Mauá moralmente (como ele o admitia repetidas vezes em sua Exposição aos credores). Salientemos que também foi Mauá partidário da abolição da escravatura: "Não sou suspeito; então, agora e sempre, ambiciono ver desaparecer o elemento escravo da organização social do meu país", escrevia ele em 1878, em sua Exposicão aos credores, referindo-se ao que pensava por volta de 1838.

Em verdade, quando se lê o livro Em busca de Lincoln de Vianna Moog, não nos parece que Mauá fique, em todos os sentidos, em posição inferior à grande figura da história dos E.U.A., seja pela estatura moral, seja pelo espírito humano, seja pelo espirito científico que revelou ${ }^{8}$. Eis por que é de lamentar, a nossa ver, que o próprio Vianna Moog, nascido, como Mauá, no Rio Grande do Sul, esquecesse a figura de seu conterrâneo no livro Pioneiros e ban- deirantes referindo-se a ele apenas em curta nota de pé de página, sobretudo quando se considera que Mauá foi, sem dúvida, o maior pioneiro e bandeirante do Brasil após sua independência política.

Sobre a mentalidade vanguardeira de Mauá, não olvidemos que seu discurso de 1851 já nos revelava distinguir ele, claramente, o sentido de 'ciência pura' e 'ciência aplicada'. Isto quando sugeria que a descoberta das leis da natureza pelos sábios ou homens de ciência permitia, com a técnica e a atividade empresarial, movida pelo espírito de associação, obtivesse o homem desenvolvimento industrial para seu bemestar.

Notemos igualmente que o mesmo discurso nos indica que Mauá parecia já estar familiarizado com a obra do maior economista clássico da época. John Stuart Mill, igualmente uma das maiores expressões intelectuais, como lógico e como filósofo, do século XIX. Evidência do conhecimento da obra de Mill, cuidamos encontrá-la no fato de fazer Mauá apologia do 'espírito de associação' e aludir ao progresso pela aplicação das descobertas científicas, em termos que lembram o que Mill escreve, no livro VI, capítulo 1, de seus Principles of political economy (1846). Ali, efetivamente, além de se referir ao 'espírito de associação', por meio de empresa por ações, Mill nos fala sobre o domínio da natureza, pela aplicação das suas leis com a ajuda do talento prático dos empresários: - "A mais maravilhosa das invenções modernas - escrevia Mill - a que realiza as façanhas imaginárias do mágico, não no sentido metafórico, mas na realidade - o telégrafo eletromagnético - apareceu poucos anos depois que se estabeleceu a teoria científica". Não parece evidente haver no discurso de Mauá influência do que Mill escreve aí? De qualquer maneira, não esqueçamos que Mauá jamais aceitou os equívocos de Mill relativamente à teoria da moeda metálica e à crença no equilíbrio econômico natural por força da oferta e procura, dentro do regime do laissez-faire e do padrão ouro, precisamente o erro que lhe viria a apontar Keynes, com a publicação de sua General theory, em 1936.

\section{Crítica de Mauá ao terceiro Banco do Brasil}

O fato de rejeitar Mauá a teoria clássica da moeda vai levá-lo a discrepar da doutrina monetária que inspirou a criação do terceiro Banco do Brasil, ou seja, o segundo banco emissor com atribuições oficiais. O embrião desta discrepância aparece em documento escrito por Mauá, em 1853, ainda como presidente do Banco por ele fundado, e às vésperas da criação do terceiro Banco do Brasil. Trata-se de memorial, dirigido pelo Conselho de Administração 
do banco, presidido por Mauá, ao Ministro da Fazenda, na época José Rodrigues Torres, futuro Visconde de Itaboraí, aquele que tomou a iniciativa de fundar o terceiro Banco do Brasil.

O memorial de 1853, assinado por Irineu Evangelista de Souza, como presidente do referido Conselho, é documento também da maior importância histórica, a nosso ver. Poisé a primeira vez, segundo temos conhecimento, que Mauá manifesta sua discordância da teoria ortodoxa da moeda ouro. Esse escrito encontra-se, por assim dizer, perdido na massa de documentação do Relatório da Comissão de Inquérito de 1859, a que nos referiremos adiante. Vale salientar que já então, há 129 anos, Mauá compreendia que o crescimento da renda nacional exigia correspondente aumento de meio circulante para evitar a depressão econômica.

Constatando que uma tendência depressiva ocorria em 1853, Mauá propunha ao Ministro da Fazenda medidas destinadas a aumentar o meio circulante, já que o Brasil não possuía ainda, como dizia, adequado Banco emissor (que então se cuidava de fundar com a fusão do banco criado por Mauá e do Banco Comercial). Embora aceita a sugestão do memorial, Rodrigues Torres (Itaboraí) tinha idéias monetárias opostas às de Mauá. Adepto da moeda metálica, fundou ele o terceiro Banco do Brasil partindo de conceitos e de um encargo com o qual o espírito de Mauá não poderia concordar. Referimonos ao encargo desse banco, de resgatar, anualmente, 2.000.000\$000 de papel moeda, visando com isso à conversibilidade metálica do 'mil-réis'.

Mauá nos fala, na 'Exposição aos credores', de sua resistência para a criação de tal Banco. Entretanto, depois de muita insistência de Itaboraí, cedeu, "abrigando a esperança - dizia - de concorrer para que a grande instituição de crédito, que se ia criar, inoculasse na vida econômica e financeira do país uma nova era de desenvolvimento e progresso". Assim, concordou na fusão de seu banco com - Banco Comercial, havendo tomado parte ativa na organização desse terceiro Banco do Brasil, do qual foi eleito um dos diretores. Manejos eleitorais haviam dado, porém, ingresso na Diretoria a alguns que the eram hostis, com a exclusão de outros que se achariam ao seu lado nas votações. "Em tais circunstâncias - diz Mauá - recusei o cargo." Afastado da direção do Banco, aguardou o seu desenvolvimento, "observando atentamente os movimentos do vasto mecanismo de crédito que o amálgama dos interesses concentrados nos dois Bancos representava - fortalecidos ainda - escrevia pelos privilégios e concessões que foram outorgadosao novo Banco do Brasil".

Mauá esperava que o grande banco estabele- ceria uma caixa filial", como se dizia então, "em todas capitais das vinte províncias do Império, além de mais algumas localidades onde regular desenvolvimento econômico se fosse manifestando". Para Mauá, o Banco do Brasil tinha, pois, "a missão de tornar conhecido o uso do mais poderoso instrumento de civilização moderna - o crédito - no tocante à criação da riqueza em toda a extensão do território pátrio". Esperava, enfim, que o novo mecanismo de crédito levasse - são suas palavras "a vida ao capital inerte (por assim dizer em dormência), que superabunda em todos os cantos do Brasil, convertendo em instrumentos de produção recursos dispersos e inutilizados para a criação da riqueza, individual e conseqüentemente nacional". Era a perspectiva - acrescentava - "que se me afigurava como conseqüência da organização do grande Banco do Brasil, o que só podia justificar o monopólio prático e legalmente criado".

Como procedeu, porém, o Banco do Brasil, com seu monopólio pela fusão dos dois bancos, ao mesmo tempo que se instituía com o princípio errôneo de resgatar papel-moeda do Tesouro? "Encarava-se o Banco do Brasil - responde Mauá - como uma grande caixa de descontos 'local', que devia realizar essas operações pela taxa mais alta que fosse possivel obter, sendo o princípio regulador a maior ou menor confiança dos diretores nas firmas oferecidas". Além disso, prossegue, "a criação das caixas filiais encontrava resistência tenaz, e qualquer operação de finanças nem era compreendida". Em presença desse fatos, exclamava "quase desanimei! Era ainda, essa a época das maiores aspirações de minha alma... Não sonhava eu então senão com as idéias que entendiam com a prosperidade de minha pátria".

Desapontado, resolveu Mauá fundar outro banco particular, em 1854, aquele que viria a ser 0 grande Banco Mauá que realizaria, como nos escreve em sua Exposição, o ideal que o Banco do Brasil na época não alcançava, espalhando agências por todo o país com filiais no exterior. Foi esse Banco, como declara, um verdadeiro 'monumento nacional'9. Isto, até o momento em que, diante de dificuldades, surgidas vinte anos depois, com as filiais no Uruguai onde protegeu os interesses do Brasil, o Governo Federal negou-lhe o apoio que Ihe devia, recusando-lhe o próprio Banco do Brasil um empréstimo de três mil contos de réis caucionados pelos melhores títulos. Assim, em 1875 se abateu o 'grandíssimo colosso', ou seja, 'poderoso dínamo criador de riquezas' como escreveu o diplomata Teixeira Soares em seu livro O Gigante e o rio (1957). Saliente-se que, para as dificuldades do banco de Mauá, contribuiu, também, consideravelmente, a legislação metalista da moeda, que fora imposta ao país. 


\section{Controvérsia entre pluralidade e} unidade emissora

Lembremos que, se, por um lado, o período de 1850 a 1858 foi dos mais fecundos no desenvolvimento econômico do país, por influência do pensamento e do espírito pioneiro de Mauá, por outro lado, foi esse igualmente o período (sobretudo depois da fundação do terceiro Banco do Brasil) do maior debate já travado no país em torno de concepções monetárias e bancárias relacionadas com a capacidade emissora em relação aos metais preciosos. 0 exame da documentação da época revela ter sido Mauá o único que nos legou argumentos originais na dura luta intelectual que empreendeu para evidenciar que o grande obstáculo (que seus antagonistas não percebiam) para o desenvolvimento era a concepção metálica da moeda.

Conquanto seja a doutrina da unidade bancária emissora e não a de pluralidade a que veio a prevalecer nãó é possível deixar de dar razão a Mauá e a Souza Franco, o ministro da Fazenda que permitiu a pluralidade bancária emissora, ao tempo em que a escola unitária não compreendia aumento do meio circulante sem vinculação com o lastro ouro. As ligeiras inflações que disso resultaram foram insignificantes em comparação com aquela que continua e há cerca de 35 anos corrói as instituições nacionais, tendo ultrapassado os $100 \%$. Contra a escola metálica, porém, que conduzia à depressão, se insurgiu Mauá, em defesa do desenvolvimento e dos interesses do Brasil, procurando mostrar o mal que constituía o monopólio emissor com base nos metais preciosos. Compreendia ele claramente que a doutrina das emissões vinculadas ao ouro, dada a escassez deste metal, constitụia entrave ao progresso econômico. Daí sustentar que o ouro deveria antes ser enviado para o exterior, a fim de importar bens de que o país necessitava para o seu desenvolvimento, como sugeria já em seu memorial de 1853.

A leitura dos discursos e debates de Mauá, como deputado na Câmara do Império, sobretudo com adversários como Sales Torres-Homem, depois feito Ministro da Fazenda e Presidente do Banco do Brasil, evidencia sua poderosa argumentação lógica, contra a qual pouco podiam seus contendores. O ápice do debate surgiu como decorrência da crise econômica que se verificou nos E.U.A. em 1857 e teve reflexos na economia brasileira com a queda de nossas exportações e conseqüentemente alta da taxa de câmbio, o que obrigava o Brasil a remeter para o exterior seu ouro. "Essa crise - escreveu Mauá em sua Exposição aos credores, - patenteou, logo no seu começo, o débil esteio em que os homens da escola metálica se apoiavam para firmar o sonho dourado de realizar a conversão metálica do nosso papel-moeda, e que eu considerei sempre im- praticável (exceto durante raras intermitências)". Assinalava Mauá que, com o desequilíbrio na balança de comércio, provocado pela redução de exportações, o ouro "que fazia momentaneamente as funções de meio circulante, em concorrência com o papel-moeda, converteu-se repentinamente 'em mercadoria', que teve de ser desde logo exportada para suprir o déficit que a queda do valor dos produtos acarretava".

Em verdade, muito antes de seus escritos de 1878, Mauá em seu depoimento publicado no Relatório da Comissão de Inquérito de 1859, há 123 anos portanto, nos apresentava um dos mais notáveis trabalhos de crítica da doutrina metálica, com lições sobre os efeitos na taxa cambial com o desequilíbrio no balanço de pagamentos. Opondo-se aos partidários da moeda metálica de então, como Itaboraí, Torres-Homem, Angelo da Silva Ferraz, (todos estes ocuparam cargos de Ministros da Fazenda), advertia Mauá com propriedade naquele depoimento: - "seria anacronismo pretender hoje medir a riqueza de um país pela quantidade de ouro ou de prata que nele circule; pode um país ter muito ouro e muita prata e ser pobre, como pode ter pouca prata e pouco ouro e ser entretanto rico. A decadência e o empobrecimento da Espanha datam da época em que o oúro da América começou a despenhar-se às torrentes em seus mercados".

Asseverava com sabedoria Mauá que "o meio circulante é o poder de adquirir; ora, sendo assim, o que importa que esse poder seja simbolizado por uma tira de papel ou por uma moeda de ouro?" No primeiro caso, dizia, "para operar a transmissão dos valores emprega o país um instrumento que não tem valor intrínseco; no segundo opera essa transmissão por meio de instrumento dispendioso que absorve uma grande parte do capital do país".

É importante, porém, lembrar aquilo que já ressaltamos em nosso referido livro, isto é, que o pensamento antimetalista de Mauá não deve ser confundido com o de um partidário do inflacionismo. Em seu referido depoimento o Relatório de 1859, ele percebia que o problema não estava na qualidade do dinheiro e sim na quantidade: "É inegável - observava - que por toda parte abusos se têm dado, que prejudicam grandemente o poder de aquisição simbolizado por essas tiras de papel. Mas - perguntava - o que devemos condenar, o uso ou o abuso?" Assim, se manifestava ali pela limitação da expansão do papel-moeda, como o fará em seu O Meio circulante de 1878, onde apresenta argumentação metodológica mais amadurecida. No entanto, no mesmo depoimento, na polêmica contra os metalistas, proclamava: - "Ousarei discordar desses que tanta celeuma levantam contra as camadas de papel, manifestando minha íntima convicção 
de que a circulação de um papel bancário, bem garantido embora inconversível, uma vez que sua emissão seja contida por certos limites em lei, é um grande bem"10.

Não obstante sua bem fundada argumentação antimetalista, os partidários da moeda ouro, ou nele conversivel, lograram fazer passar uma lei a 22 de setembro de 1860 , contrária ao desenvolvimento, pois só permitia a emissão de papel-moeda com base em ouro. Isto depois do grande período de prosperidade com a pluralidade bancária emissora. Esta lei de 1860, era, para Mauá, o maior absurdo que já se praticara até então no Brasil. Lê-se em seu O Meio circulante de 1878: - "Desde 1850, alguma conversão em valores permutáveis se havia operado nos recursos naturais do país, devido ao espírito de associação, que nessa época começara a dar os primeiros passos. Esse surto do progresso - dizia Mauá, "assustou por tal forma os rotineiros, que desde logo cuidaram em atar as pernas ao gigantes, com receio de que caminhando pudesse cair!". Assim, "'as restrições violentas que a lei de 22 de agosto de 1960 criara, deram em resultado a crise bancária de 10 de setembro de 1864 ".

Mauá se refere aí à famosa crise que levou à chamada 'quebra do Souto', ou seja, à falência da casa bancária Alves Souto que ficou celebre nos anais da história econômica e social do Império. O que é importante notar, porém, é que sempre que surgia uma crise, a primeira coisa que se fazia no lmpério era amparar o Banco do Brasil, suspendendo a obrigação de conversibilidade metálica de suas notas, a fim de não Ihe criar dificuldades. Em segundo lugar, entre as medidas tomadas, estava a de imprimir papel-moeda, para evitar crise maior. Assim foi em 1864, em 1875e 1878, o ano em que Mauá, já levado à falência, escreveu seu ensaio O Meio circulante do Brasil, a fim de dar melhor cobertura ao governo para a emissão necessária de papel moeda que então se fez, para remediar a situação depressiva da época. Importa, porém, fixar que a política de emitir e amparar o Banco do Brasil vai contrastar com a atitude tomada na República pelo governo de Campos Sales, com relação ao referido Banco da República do Brasil, quando seu Ministro da Fazenda Joaquim Murtinho praticou insana política que levou esse Banco à liquidação em 1900 e, com isso, à maior deflação monetária de nossa história, como antes referido.

Não conhecemos qualquer outro escrito de Mauá depois de 1878, quando, já com 65 anos, escreveu não só O Meio circulante do Brasil, mas a Exposição aos credores, em que relata sua vida de empreendedor que teve como prêmio, pela incompreensão e ingratidão dos dirigentes na época, a falência do grande conjunto de sua empresas de interesse nacional. Saliente-se que essa falência, so- mente decretada em 1878, deve-se ao fato de não existir na época a lei da concordata, que por certo o teria salvo. De qualquer maneira, além de o Imperador não o haver amparado, contribuiu para a negação do empréstimo que solicitara ao Banco do Brasil, a influência de um diretor, seu desafeto pessoal, o conselheiro Pereira da Silva. Partidário do padrão ouro, era este acusado de não ser muito escrupuloso em seus negócios, segundo indica a documentação em que se funda o bisneto de Mauá, Claudio Ganns, no prefácio do livro que denominou Autobiografia de Mauá (1942).

Ferido pela ingratidão, mesquinhez ou incompreensão, Mauá, em sua Exposição de 1878, depois de relatar suas grandes realizações pelo progresso do Brasil, escreve na parte final, a respeito do duro golpe que recebeu: "A falência (em 1878) significava apenas torcer o punhal, que me haviam cravado no coração em 17 de maio de 1875, para que a dor fosse mais funda. Destruída a fortuna, abatido o nome, que mais queriam agora? Meu único crime foi trabalhar muito, tendo sempre por norma fazer algum bem". Terminava com estas palavras: "Só me resta fazer votos para que no meio século que se segue, encontre o meu país quem se ocupe dos meIhoramentos materiais da nossa terra, com a mesma fervorosa dedicação e desinteresse (digam o que quiserem os maldizentes) que acompanhou os meus atos durante um período não menos longo, serviços que tiveram em recompensa um procedimento desnecessário... Pela parte que me toca fui vencido, mas não convencido"

Seis anos depois de sua falência, na qual se houve com a maior nobreza e estoicismo, procurando reduzir ao mínimo os prejuízos de seus credores, Mauá foi reabilitado pela Justiça vindo a falecer cinco anos depois, em 1889., dois meses antes da Proclamação da República. Posteriormente Tristão de Ataíde, escrevendo para o inquérito - $\dot{A}$ Margem da História da República (p. 250/251) sintetizou a vida do grande homem nestas palavras: - "O precursor admirável, essa figura realmente única em nossa história - o Visconde de Mauá, - desde a Maioridade até a República, acompanhando a realeza imperial com a sua realeza econômica, na ascensão $€$ na decadência, pressentiu e tentou resolver todos ou quase todos os grandes problemas econômicos brasileiros, os problemas essenciais do período moderno de nossa história, desde os interesses do Rio Grande, que representou na Câmara, até à navegação do Amazonas. Foi um quadro assombroso de unificação nacional na cabeça de um só homem, o Caxias da unidade econômica" (ensaio Política e Letras, publicação coletiva, ed. do Anuário do Brasil, 1924).

Todavia, aquilo que nos esforçamos por res- 
saltar aqui e noutros trabalhos, relativamente ao espírito científico de Mauá como crítico da econômica política, não foi, ao que saibamos, posto em relevo e compreendido, igualmente, por seus biógrafos mais entusiastas como por exemplo, Alberto de Faria e Claudio Ganns.

\section{Mauá e o Brasil de nossos dias}

Decorrido mais de século da publicação de dois dos mais importantes escritos legados por Mauá, que lição podemos tirar de sua vida e de seu pensamento econômico para o Brasil de hoje, vítima de usurárias taxas de juros, em meio a uma crônica inflação de quase quatro décadas, que conduziu à opulência de uma minoria em contraste com extrema miséria.

Em primeiro lugar, pode-se dizer que a dramática conjuntura a que chegamos, se deve, consideravelmente, ao atraso em que se tem mantido a Economia Política, criticada por Mauá, atraso que persiste apesar das contribuições de Keynes, não confundido - insistimos - com o 'Keynesianismo vulgar'. Este, responsável pela crise de 'estagflação' (inflação com desemprego) enfrentada pelas próprias nações mais desenvolvidas, e que, obviamente, como acentuado na 'Introdução', agrava nossas condiçőes de hiperinflação e suas conseqüências nefastas, inclusive o endividamento externo e interno:

Com relação às elevadas taxas de juros, negadas pela análise da Teoria geral de Keynes, valeria lembrar que, além das referências feitas à crítica de Mauá à exigência de tais taxas pelo terceiro Banco do Brasil, encontramos também na Exposição aos credores a asserção de que o alto juro 'é a víbora que devora as raízes da produção'. Concebia mesmo ali Mauá que aquele Banco poderia fazer empréstimos a $1 \%$ ao ano, "visto que - dizia - não empresta o capital de seus acionistas, porém, o seu crédito que é também do país". Argumento que nos faz pensar possa ele haver lido a famosa polêmica ProudhonBastiat, no meio do século XIX, na qual o primeiro defendia a substituição da taxa de juros do Banco da França - tendo implícito o macroequilíbrio econômico - por taxas módicas de serviços bancários ${ }^{11}$. Pode-se assim concluir que o pensamento de Mauá sobre o juro tem afinidades não só com o de Proudhon, mas também, como sugerido, com o da Teoria gera/ de Keynes. Este revela, como Mauá e o alemão Silvio Gesell, exaltado na obra do economista inglês, que o alto juro freia o processo produtivo, chegando Keynes a concordar com a doutrina da Igreja Medieval que o condenou: 'Um governo sábio - escreve - deve coibir o juro pelo costume, pela legislação e mesmo invocando as sanç̋̃es da lei moral". (p. 351, General theory).
Por outro lado, no que tange à inflação, foi antes evidenciado que Mauá, ao defender o papelmoeda e o crédito a taxas módicas de juro, enfatizava que o importante era que, por lei, se impedisse, 'não o uso, mas o abuso', ou seja, o volume excessivo de meio circulante, o que indica, em termos atuais, a busca de uma demanda global adequada para evitar o desequilíbrio inflacionário. Mauá afirmava ainda que a função do dinheiro era a de servir de 'motor das transações', conceito que se identifica com a teoria da moeda de Pierre de Boisguillebert (1647-1714), o grande pioneiro francês da economia política. Este, que também vetava a moeda ligada ao ouro, asseverava com veemência que, para prevenir a estagnação econômica, o dinheiro deveria ser um perpetuum mobile, expressão usada por Marx, embora não tivesse este compreendido o pensamento monetário positivo daquele que ele próprio considerava o fundador da economia política na França ${ }^{12}$.

A tese de que a moeda deve ser 'motor de transaçðes', sob implícitas condiçðes de macroequilíbrio econômico, coincide também com as de Gesell e de Keynes ao analisarem os efeitos nocivos da preferência pela liquidez', isto é, pelo entesouramento ou retirada de circulação do dinheiro com o objetivo de transformá-lo em 'reserva de valor'. Isto porque, se contraída a demanda global, a comunidade é lançada na depressão e no desemprego. Evidentemente, em nossos dias, sob elevada taxa de inflação como a dominante no Brasil, ninguém, afora 'lunáticos' dizia Keynes - prefere o dinheiro entesourado, pois em tais condições este perde poder aquisitivo com a alta do nivel de preços. Entretanto, ocorre hoje, não só no Brasil, mas em outros países inflacionados, um tipo de entesouramento ou preferência por dinheiro líquido na forma de dólares, já que a moeda dos E.U.A. passou a ter, sob a égide do irracional F.M.I., criado em 1944, o privilégio de se tornar a 'moeda de reserva' mais desejada. Isso contribui para desequilibrar a economia de nações cujos indivíduos, empresas e mesmo governos guardam dólares em cofres particulares e, em maior volume ainda, depositados em bancos no exterior. Não cabe aqui detalhar os males bem conhecidos dai decorrentes e que levaram recentemente o presidente do México, Lopez Portillo, a rebelar-se contra aquele procedimento de seus concidadãos e à adoção de medidas drásticas, como a estatização do sistema bancário, sem, porém, desrespeitar a economia de mercado.

Contudo, cumpre consignar que os males e problemas assinalados, decorrem, a nosso ver, das obscuridades e ambigüidades da Teoria geral de Keynes e das contradições deste em Bretton Woods, ao dar apoio ao F.M.I. definindo as moedas das nações em termos de dólar dos E.U.A., vinculado ao ouro ${ }^{13}$. Com isso, abandonou Keynes seu pró- 
prio plano para uma Câmara Mundial de Compensação (Internacional Clearing Union), a qual, ao contrário do F.M.I., estabelecia, por engenhoso mecanismo, equilíbrio automático na balança de comércio internacional. Com uma nova moeda. bancor, que negava o privilégio do dólar como 'reserva de valor'14 e que evitaria a imensa dívida dos paises do Terceiro Mundo. A atitude de Keynes concorreu também, em nosso entender, para fazer surgir o keynesianismo vulgar e suas conseqüências negativas. Salientemos que, em contraste com as ambigüidades de Keynes, nosso Mauá, tal como os outros economistas heterodoxos mencionados, foi sempre coerente em sua crítica aos erros da economia clássica em relação à moeda ouro e ao alto juro.

\section{Conclusão - As reformas inspiradas em Mauá}

Se válida a argumentação desenvolvida neste e noutros trabalhos, cuidamos em nosso país, inspirado na racionalidade do pensamento de Mauá e liderando nações do Terceiro Mundo, poderia e deveria assumir a crítica da cidadela do erro da economia mundial que é o F.M.I. e propor, dentro do espírito do discurso do Presidente Figueiredo na ONU, sua transformação na Câmara Mundial de Compensação de Keynes, devidamente atualizada, a fim de eliminar a regalia danosa concedida ao dólar como moeda de reserva ${ }^{15}$. É evidente que essa reforma monetária no plano internacional requer paralelas reformas financeiras de âmbito nacional que substituam o juro por taxa módica de serviços bancários. A respeito destas reformas, talvez fossem mais viáveis, em nosso país, se começasem por tornar o Banco do Brasil, bem como dos Estados (BANERJ, BANESPA, etc.) entidades de direito público ${ }^{16}$ que aplicassem a política de crédito sugerida por Mauáe demais economistas citados. É óbvio, como se infere da teoria monetária e bancária racional, que a finalidade daquelas instituiçøes (e de outras) é a de contribuir para o desenvolvimento equilibrado por um suprimento adquado, à comunidade, de moeda e crédito, em termos de demanda global efetiva, para evitar inflações e depressões e promover a distribuição da renda com justiça. Esta ocorre, nas condições de estabilidade monetária e pleno emprego, pela afirmação de duas leis, de correlação inversa, da própria economia de mercado, a saber, a lei dos salários crescentes, pela concorrência e aumento de produtividade, e a da queda da taxa média de lucro, o que exige a redução da taxa de juros para evitar queda no volume de investimentos e de emprego. As duas leis foram detectadas pela análise de Marx como simples tendências em virtude das crises que interrompiam o processo de desenvolvimento ${ }^{17} \mathrm{e}$ que agora voltam em decorrência da função prejudicial do dólar como 'moeda de reserva' e dos altos juros bancários, após razoáveis período $(1950 / 70)$ de desenvolvimento equilibrado nos países mais industrializados.

No processo de real reforma financeira, buscando manter, efetivamente, macroequilíbrio econômico e o pleno emprego, cremos de todo conveniente que os economistas dirigentes das instituições encarregadas de manter o país livre da inflação e do desemprego, com moeda estável, fossem indicados pelas Confederações do Comércio, Agricultura e Indústria e pelos departamento de economia de Sindicatos - dos quais o Diese, dos metalúrgicos do ABC é promissor exemplo, deixando de lado aqui sua controvertida ideologia. No entanto, para prevenir os males do 'estatismo', a segunda medida necessária seria a de legislação específica relativamente à responsabilidade daqueles dirigentes no sentido de manter a ordem econômica equilibrada. Assim, parece justo que devessem sofrer sanções, como a de demissão, sempre que permitissem variação no adequado índice de preços, além de certo limite - digamos de $5 \%$ - ou queda no volume de emprego. A legislação alvitrada se louva não só no pensamento do eminente economista americano Irving Fisher, o qual, em seu livro $100 \%$ Money, aventou a criação de uma espécie de Supremo Tribunal Monetário para julgamento de infrações cometidas contra a estabilidade do valor da moeda, mas também no do próprio Mauá quando exigia a força da lei para coibir abusos na expansão do meio circulante. Entretanto, nosso Banco Central, por exemplo, encarregado do controle da demanda (monetária) global para prevenir desequilíbrios inflacionários lou depressivos) não contêm cláusula alguma que responsabilize seus dirigentes a esse respeito.

É claro que as reformas financeiras, no plano nacional, têm implícita adequada política tributária e agrária. E, no campo internacional, também a proposta de completa desmonetização do ouro, pela venda, no mercado livre, dos estoques F.M.I. e dos Bancos Centrais, rompendo, assim, de uma vez, com o mito milenar. Isso não só faria baixar o preço artificialmente alto desse metal para usos realmente úteis, como retiraria da U.R.S.S. e da Africa do Sul as vantagens atualmente usufruídas por essas duas nações, maiores produtoras de ouro e que não primam pelo respeito aos direitos humanos.

Sumariamente, essas são as reformas que, se bem traduzidos foram, para os dias atuais, os princípios defendidos por Mauá, teriam - imaginamos seu apoio. E se Mauá é, verdadeiramente, o maior dos economistas da nacionalidade, então não se impõe ele como patrono de todas aqueles que hoje rejeitam também idéias apregoadas com dogmática 
severidade pelos chamados mestres da ciência mas que não resistem à 'ação e pressão dos fatos', no plano nacional e internacional?

À guisa de apêndice, convém trazer à baila, no que concerne à apologia de Mauá, questão já tratada em escritos anteriores. Referimo-nos às diferentes interpretaç̃es do seu significado histórico em nosso país por correntes influenciadas pela ideologia marxista. A primeira dessas interpretações foi expressa pelo professor de direito Castro Rebelo, em seu livro Mauá - Restaurando a verdade (1932), antagônico à obra Mauá de Alberto de Faria. Pretendendo negar a grandeza de Mauá, Castro Rabelo, entre outras considerações - a nosso ver infundadas - atribuíu-lhe, pejorativamente, 'interesses de mercador', endossando expressão originalmente usada por Gaspar da Silveira Martins, conterrâneo de Mauá e seu adversário no Parlamento do Império. Deve-se dizer que o impetuoso tribuno, posteriormente chefe do Partido Federalista no Rio Grande do Sul, com o advento da República não deixou pensamento algum de conteúdo superior e, ao contrário de Mauá, não tomou posição quanto à abolição da escravatura. Sua incompreensão da importância do empresário e economista, conflita com a opinião de Ruy Barbosa sobre Mauá, em sua obra Financas e política da república. A propósito destas divergências, lembremos que, na Câmara do Império, Ruy, noviço deputado, enfrentou vitoriosamente o desdém com que Silveira Martins pretendeu tratá-lo.

Contrastando no entanto com a posição de Castro Rebelo, historiadores de influência marxista, no vol. 7 da Coleção história nova, apreendida em 1964, enaltecem Mauá com entusiasmo como elemento dos mais positivos no processo de desenvolvimento econômico do país. Outros, porém, ainda hoje, 0 acusam de ter sido representante do imperalismo inglês da época, ignorando que Mauá, na realidade, foi vítima de verdadeira chantagem dos banqueiros Rotschild, como deixou registrado em sua Exposição aos credores. Da mesma forma, sofreu hostilidade de parte do London and Brazilian Bank - como é admitido mesmo pelo historiador inglês David loslin ${ }^{18}$ - e ainda a injustiça dos tribunais ingleses com os quais lutou, em vão, na defesa de seus direitos relativos a uma das estradas de ferro que implantou (Santos - Jundiaí). Esua luta contra o padrão-ouro não o era também contra a própria libra (ouro) símbolo daquele imperialismo na Era Vitoriana? ${ }^{19}$

Seja como for, se conseguimos comprovar que são de extraordinária relevância as contribuiç̃es de Mauá, no campo do desenvolvimento econômico e na crítica da economia política, não parece então que o 'evangelista do progresso nacional' de- veria ter seu pensamento mais objetivamente difundido, pela inclusão do estudo específico de suas obras nos programas de nossas faculdades de economia? ${ }^{20}$ Ao lado disso, cuidamos ainda que seria desejável a criação de um 'Instituto Mauá de Economia Política' - tal como se criou no Recife o Instituto Joaquim Nabuco ${ }^{21}$ ou no Rio a Fundação Getúlio Vargas - dedicado à pesquisa naquela disciplina, e que tratasse da publicação de todos os seus escritos, correspondência e discursos proferidos no Parlamento do Império, como se faz em outros países para seus grandes vultos. Na Inglaterra, por exemplo, no que tange à economia política, lembremos a edição das obras completas de David Ricardo e mais recentemente as de John Maynard Keynes, os quais não sobrepujam o nosso Mauá, seja na contribuição que deixou, o primeiro, seja na coerência e integridade científica, o segundo.

Por último, ousamos pensar que, da mesma forma que na capital dos E.U.A. se erigiu o 'Lincoln Memorial', seria também justificável a idéia de se erigir, em nossa capital, um Panteon a Mauá, para reverenciar a memória daquele que, além de haver promovido investimentos básicos para o Brasil de seu tempo, deixou idéias que, acreditamos, poderão contribuir para que nosso país e outros do Terceiro Mundo possam, de fato, alcançar desenvolvimento econômico e social equilibrado. Isto, se unidos, lograrem rejeitar instituiçðes e normas que lhes foram impostas pelas naçðes mais ricas, verdadeiro 'presente grego' - como diria, de novo, Mauá. Ėo caso daquelas emanadas do F.M.I. e outras entidades que estão impedindo o advento de uma Nova Ordem Econômica Mundial, sob racional economia de mercado, como alternativa distante das injustiças do capitalismo das crises e do coletivismo marxista.

\section{Notas}

1. Este ensaio constitui desenvolvimento de artigo publicado em O Globo por ocasião do $160^{\circ}$ aniversário (1968) da fundação do primeiro Banco do Brasil. O espirito encomístico que o anima será talvez considerado excessivo por alguns, particularmente aqueles influenciados pela ortodoxia marxistaleninista. Mas supomos que ele representou reação compensatória ao fato de terem passado despercebidos os relevantes (e atuais) subsidios de Mauá à crítica da economia política, sobretudo hoje em face do descrédito universal dessa disciplina, decorrente da crise mundial na qual estamos envolvidos.

2. Ver São Paulo, Ed. Civilização Brasileira. Marx, defensor do padrão ouro. IN: Das Kapital.

3. Colóquio sobre Boisguillebert, Rouen, 1975 e Congresso sobre Malthus, Unesco, Paris, 1980. As comunicações apresentadas a esses congressos têm, respectivamente, os seguintes títulos: La Dialectique de l'équilibre de Boisguillebert face à la dialectique de Marx e Malthus, Keynes, Gesell, Proudhon and Boisguillebert in the struggle for a world free from economie disequilibria.

4. Foide tal ordem a consolidação, por Marx, do mito do ouro como base da moeda, que o Presidente da França, Mitterrand 
- socialista de influência marxista - propõe, em seu livro Lei et maintenant, 1980, uma reforma do sistema monetário mundial com 'certo retorno ao ouro'. Isto porque, diz ele, "o ouro, ao preço atual, representa cerca de $60 \%$ das reservas mundiais" e "nada se pode fazer contra o fato". Eis prova eloqüente do retardo em que se encontra a economia política por força de dogma contra o qual se voltaram nosso Mauá e os franceses Boisguillebert e Proudhon, cuja teoria da moeda ametálica não foi compreendida por Marx.

5. Expressão usada pelo economista sueco Arel Keijonhufrud (radicado nos E.U.A.) em sua obra On Keynesian economics and the economics of Keynes, para caracterizar os chamados keynesianos que não interpretam corretamente principios da teoria de Keynes. Para nós, ela abrange a omissão da denúncia do F.M.I., como uma contradição do pensamento de Keynes.

6. Como assinalado em trabalhos nossos sobre Mauá, antes mencionados.

7. Ver SALLES, Campos. Vieira Souto e o mito Murtinho..IN: Ouro - A Reliquia bárbara.

8. Viana Moog, intrigado com o mito de Lincoln como simples lenhador com instrução primária apenas, fez intensa pesquisa nos E.U.A. para evidenciar que Lincoln adquiriu, informalmente, cultura maior, não só através de leitura mas também pelo ensino didático com homens de educação de nivel superior. Não mereceria o conterrâneo de Viana Moog investigação semelhante? Supomos haver dado acima alguma prova nesse sentido. Não esqueçamos que, na Exposição aos credores, Mauá observava: "minhas conversas com homens de ciência eram constantes". Por certo se referia aos engenheiros trazidos por ele da Europa para seus diversos empreendimentos industriais, os quais, obviamente, teriam formação cientifica.

9. Júlio Verne, em sua Viagem à lua, menciona o Banco Mauá no Rio e suas filiais montevidéu e Buenos Aires entre os que poderiam receber subscriçø̃es para realização do projeto de ficção científica que viria a se realizar em nosso século. Essa referência do genial escritor - mencionada no livro Mauá de Alberto de Faria - dá idéia do prestígio internacional do banco de Mauá.

10. Registremos que nesse mesmo ano de 1859, Karl Marxpublicava, na Europa, sua Contribuição à crítica da economia política, onde defendia idéias a favor da moeda metálica, exatamente o gosto do que fazia Mauá no subdesenvolvido Brasil.

11. A polêmica, sob o título Interêt et principal, aparece no tomo XIX, Mélanges, da edição Lacroix, Paris, 1870 da Obras completas de Proudhon. Ver também artigo Keynes and Proudhon. Journal of Economic History, May, 1942, no qual Duddley Dillard evidencia que Proudhon, via Sílvio Gesell, é o precursor de Keynes, na oposição ao juro.

12. Ver A ATUALIDADE de Boisguillebert para a França e o mundo. IN: Ouro - A Relíquia bárbara.

13. Sobre as contradições de Keynes, ver capítulos, I, VI eX, do mesmo livro. A este respeito, são eloqüentes as palavras de seu próprio biógrafo e amigo, Sir Roy Harrod: "Houve também queixas, em Bretton Woods, de que ele abandonava a causa progressista para sujar seus dedos com um plano (F.M.I.) que envolvia ouro". The Life of John Maynard Keynes. New York, Harcourt, 1951, p. 444.

14. Na 'câmara de compensação de Keynes', o ajuste automático na balança de comércio internacional se processaria pela sugestão de se aplicar princípio de teoria monetária de Gesell, na forma de tributo ou juro negativo (crescente) aos saldos das nações credoras, a fim de compeli-las a usar esses saldos para compras à naçס̄es devedoras, restabelecendo, assim, o equilíbrio e ampliando o comércio entre elas.

15. Ver, A Solução partindo do Plano Keynes. IN: Ouro - A Reliquia Bárbara.
16. Quanto ao Banco do Brasil, essa reforma foiproposta, em 1953, em Projeto de Bilac Pinto. Diário do Congresso. (3945) 6 dez. 1953 quando deputado pela U.D.N. e defendida pela bancada desse partido. Em 1974, numa série de artigos a Revolucão e o Banco do Brasil. Tribuna da Imprensa, 22, 23 e 24 jul. 1974, propusemos igualmente o fim do Banco do Brasil como sociedade de economia mista para retirar-lhe o caráter de carro-chefe da especulação na Bolsa.

17. Sobre estas leis como tendências ver: A Lei geral da acumulação capitalista. IN: O Capital. livro I - cap. XXV, Seção I, bem como A lei da tendência decrescente da taxa de lucro. IN: O Capital - livro III.

18. A Century of banking Latin America. London, Oxford Press, 1963.

19. Há, ainda em nossos dias, os que vêem em Mauá apenas "o banqueiro ávido de lucro, esquecendo que foi Mauá, na década de $1850 / 60$, quem mostrou como criar a finança bancária - até então incipiente e insuficiente no país - o que, a rigor. dispensaria a atividade dos bancos estrangeiros de depósito que vieram a se instalar no Brasil, a partir de 1862, com o London and Brazilian Bank. Contrariando os interesses do país, provocaram em 1890, o protesto veemente de Ruy Barbosa, então Ministro da Fazenda, em famoso telegrama à nossa legação em Londres. Ver Ruy antimetalista e nacionalista. IN: Ouro - A Reliquia Bárbara.

20. $\dot{E}$ alvissareiro registrar que um intelectual da nova geração, dos mais eruditos e pretigiados, José Guilherme Merquior, professor na Universidade de Brasilia, dedica seu último livro A Natureza do processo (1982) "ao fantasma de Irineu Evangelista de Souza, Barão e Visconde de Mauá, pela 'lição' que deixou como um dos grandes modernizadores do Brasil".

21. Este, em seu Um Estadista do Império. v. 3p. 457, em nota de louvor a Mauá, faz-Ihe esta restrição: "como financeiro era, porém, um espírito sempre entrenublado pelas ficçőes do papel moeda". Interpretação equivocada que influenciou outros espiritos, partidários do padrão-ouro e contrários à apologia de Mauá. Exemplo contemporâneo disso é o do veterano e reputado jornalista liberal Barbosa Lima Sobrinho, em artigos para o Jornal do Brasil, 13 jul. 1927, 3 jun. 1971 e 25 mar. de 1973.

Caberia ainda nesta nota final atentar para a versão de Capistrano de Abreu. Em seu Ensaio e estudos. 1938. 3 ser. não hesitou em afirmar que "a década de 50 foi a mais brilhante do Império". E, referindo-se à influência de Mauá, escreve que este "firme no prestígio acumulado nos meios indigenas e fortalecido pela confiança inspirada aos capitalistas londrinos, rasgou muitas das faixas coloniais, começou a remodelar o Brasil moderno". No entanto, no mesmo texto, declara que, no "riograndense benemérito"; 0 "descortino nắo corria pareIhas com o patriotismo e a probidade". Esta ambiguidade do outro historiador decorre talvez de não haver ele logrado déscobrir a coerência metodológica de Mauá na crítica da economia política. As palavras transcritas de Capistrano-aparecem. sem assinalar-lhes a ambiguidade, no livro de PACHECO, Claudio, História do Banco do Brasil, v. 2, p. 43/4

Nota sobre a bibliografia - Nosso enfoque de Mauá como economista sintonizando com a corrente dos grandes heterodoxos (Boisguillebert, Proudhon, Gesell e Keynes, este deputado de suas obscuridades e contradições) se funda, basicamente, como indicação, em seus dois primeiros trabalhos $O$ Meio circulante do Brasil, e Exposição aos credores, bem como em seu depoimento aparecido no Relatório da Comissão de Inquérito de 1859. As edições originais destas publicações são, hoje, obras raras. No entanto, os textos integrais das duas primeiras encontram-se no livro de Cláudio Gamas, intitulado, Autobiografia de Mauá no qual, na parte final, o autor apresenta a mais extensa bibliografia que conhecemos sobre Mauá até o ano de 1942. Resumos de O Meio circulante aparece como apêndices de nosso livro Ouro - ARelíquia Bárbara e do artigo Mauá, o economista do Império, IN: Revista Brasileira de Economia, mencionados na Introdução. 